\title{
Obituary
}

\section{Zygmunt Hübner: Professional, Teacher, Diplomat}

Zygmunt Hübner, director of the Powszechny Theatre in Warsaw, whose article 'The Professional's Guilty Conscience' was published in New Theatre Quarterly 15, died, well before his time, on 12 January this year.

Some directors achieve fame or notoriety through the originality or sensationalism of their productions. There are also unsung or lesser-known directors who might be known as 'directors' directors' - the great professionals. No-one was more professional than Zygmunt Hübner. When you have worked in many theatres you acquire a sense for feeling the atmosphere of any one you enter. Something of the same applies when you go below the stands in a professional football club. All things contribute, and from the way people sit in the canteen, the way they go about their work, the way they meet in corridors, the rhythms are revealed. The Powszechny has always given me the buzz of a great team theatre, a place it would be marvellous to work in but not a place to try tricks or stand on your dignity. Great team theatres, like great football clubs, are not built overnight and need a particular kind of leadership to forge them.

What probably made this possible was the character and talent of the man himself. Hübner was not easily impressed and went out of his way not to impress his achievements on others. It was practically impossible to pay him compliments, as he had developed a way of deflecting them with ironic self-depreciation. Disconcerting as this was on first acquaintance, when you knew him it formed the basis of a lot of humorous by-play. The late Alan Schneider and I left the Powszechny Theatre one night after watching Andrzej Wajda's production of Hübner's play Conversation with an Executioner in which Hübner also played the major role. Schneider said to me, 'We ought to watch this man. He's the triple threat. Not only does he direct but he writes and acts and he does them all well.' We went back to congratulate Hübner and Schneider asked him why he didn't do more acting. Hübner replied that he liked to go home at night.

The occasion of that visit was during the Symposium on Training Theatre Directors, which Hübner organized and to which he contributed a plenary paper, 'Can Theatre Direction Be Taught?' The paper remains the single most important paper on the subject. Through his work in the State Theatre School he had much to contribute in that area.

Many of us have lost a generous and witty host and a good friend. The Powszechny Theatre has lost its leader and-a very talented colleague. The Polish theatre has lost one of its professional leaders and a great teacher. Those of us who have visited Poland and know him through his work with the Polish Centre of the ITI will also know that the theatre in general has lost a valued diplomat. To all of us he leaves the memory of his work to look back on and an example of professionalism to live up to.

CLIVE BARKER

Since this obituary notice was written, we have learned that Andrzej Wajda has been chosen as the new director of the Powszechny Theatre, which is being renamed the Zygmunt Hübner Theatre. 